\title{
RESISTÊNCIA DE CAMPO AO VÍRUS DA QUEIMA-DO-BROTO EM GENÓTIPOS DE SOJA RESISTENTES A INSETOS (')
}

\author{
ANDRÉ LUIZ LOURENÇĀO $(2,5)$, ÁLVARO SANTOS COSTA (3) \\ e MANOEL ALBINO COELHODE MIRANDA $(4,5)$
}

\begin{abstract}
RESUMO
Avaliou-se o comportamento de trinta e seis genótipos de soja em relação à incidência da queima-do-broto em condições de campo, no Centro Experimental de Campinas (IAC), no ano agrícola 1985/86. A infecção variou de 13 a 92\%, destacando-se PI $227687(13 \%)$, IAC 73-228 (25\%), IAC 80-1177 (36\%), IAC 80-1191 e IAC 84-20-1 (38\%) e PI $274453(40 \%)$ com os menores índices da doença. Os cinco genótipos menos infectados, mais a linhagem IAC 79-1823 e os cultivares IAC 9, IAC 10, IAC 12, Santa Rosa, Cristalina e IAC Foscarin-31, inoculados mecanicamente em casa de vegetação com diferentes isolados do vírus, nāo mostraram nivel de resistência semelhante ao observado em campo; nesse teste, a infecção variou de 45 a $90 \%$, tendo o melhor tratamento do experimento de campo (PI 227687) apresentado $90 \%$ de infecção. Há indicação, portanto, que a menor infecção observada nos genótipos no experimento de exposição natural seja resistência de campo, relacionada com a interação planta-tripes vetor.
\end{abstract}

Termos de indexação: Glycine max (L.) Merrill, resistência a insetos, vírus da queima-do-broto, tripes, Frankliniella.

(1) Resumo enviado ao XX Congresso Brasileiro de Fitopatologia, realizado em Londrina (PR), em 12-19 de julho de 1987. Recebido para publicação em 5 de julho e aceito em 6 de outubro de 1989. (SP).

(2) Seçâo de Entomologia Fitotécnica, Instituto Agronómico (IAC), Caixa Postal 28, 13001 Campinas

(3) Seção de Virologia Fitotécnica (IAC).

(4) Seção de Leguminosas (IAC).

(5) Com bolsa de pesquisa do CNPq. 
A queima-do-broto da soja ("Brazilian bud blight"), induzida pelo virus da necrose branca do fumo ("tobaco streak virus") foi identificada pela primeira vez no Brasil em 1955 (COSTA et al., 1955). Desde então, sua incidência em lavouras de soja no Estado de São Paulo tem sido variável em função do ano e da região (COSTA, 1977).

$O$ vírus causador da queima-do-broto da soja pode ser transmitido pela semente produzida por planta infectada (COSTA \& KIIHL, 1971), porém, até o presente, nenhuma epifitia da doença nos Estados de São Paulo e Paraná tem sico associada com essa via de transmissão. Em São Paulo há uma espécie de tripes do gênero Frankliniella que ocorre em plantas de cravorana (Ambrosia polystachya $\mathrm{DC}$ ) da vegetação espontânea, a qual transmite o virus da queima-do-broto de plantas intectadas dessa espécie para a soja (COSTA \& LIMA NETO, 1976). Entretanto, a amostra enviada por esses autores a taxonomista não foi identificada em nível de espécie. Por outro lado, tripes coletados em soja no Paraná e que também ocorrem no sul de São Paulo, foram identificados como F. schultzei (Trybom, 1910) e F. rodeos Moulton, 1933 (6). Esta última espécie foi também encontrada em cravorana no Paraná. É possivel que ambas sejam vetoras do vírus e que aumentos nas populaçōes desses tripes, bem como a presença de plantas-reservatório de vírus na vegetação espontânea, possam causar infecçōes mais generalizadas da queima-do-broto em lavouras de soja.

Para tentar controlar a doença, têm sido feitas triagens na Seção de Virologia do IAC visando encontrar germoplasma de soja resistente por meio de inoculação mecânica de isolados do vírus; até 1977, apenas D 63-4628, material não comercial , apresentou tolerância ao vírus (COSTA, 1977). Todavia, diversas introduções e linhagens resultantes do programa de melhoramento de soja para resistência a insetos, do $\mathrm{IAC}$, ainda não haviam sido avaliadas em relação a esse virus, o que constitui o objetivo do presente trabalho.

\section{Material e Métodos}

\section{Experimento de campo}

Realizou-se um experimento no Centro Experimental de Campinas, pertencente ao $\mathrm{IAC}$, em área com presença de plantas hospedeiras do virus da queima-do-broto, principalmente cravorana, e com histórico de infecção por esse virus. O germoplasma de soja estudado, juntamente com seus progenitores, encontra-se no Quadro 1; compreende 18 linhagens com graus variáveis de resistência a uma ou mais espécies de insetos e 18 cultivares.

(6) Identificaçāo feita pelo Prof. Luis de Santis, Universidad Nacional de la Plata, Argentina, em amostras enviadas pelo Dr. Flávio Moscardi, EMBRAPA, CNPSo, Londrina, PR. 
QUADRO 1. Porcentagens médias de plantas infectadas pelo virus da queima-do-broto em linhagens e cultivares de soja submetidos a infecção natural em campo e inoculaçāo mecânica em casa de vegetaçāo. Campinas, 1985/86

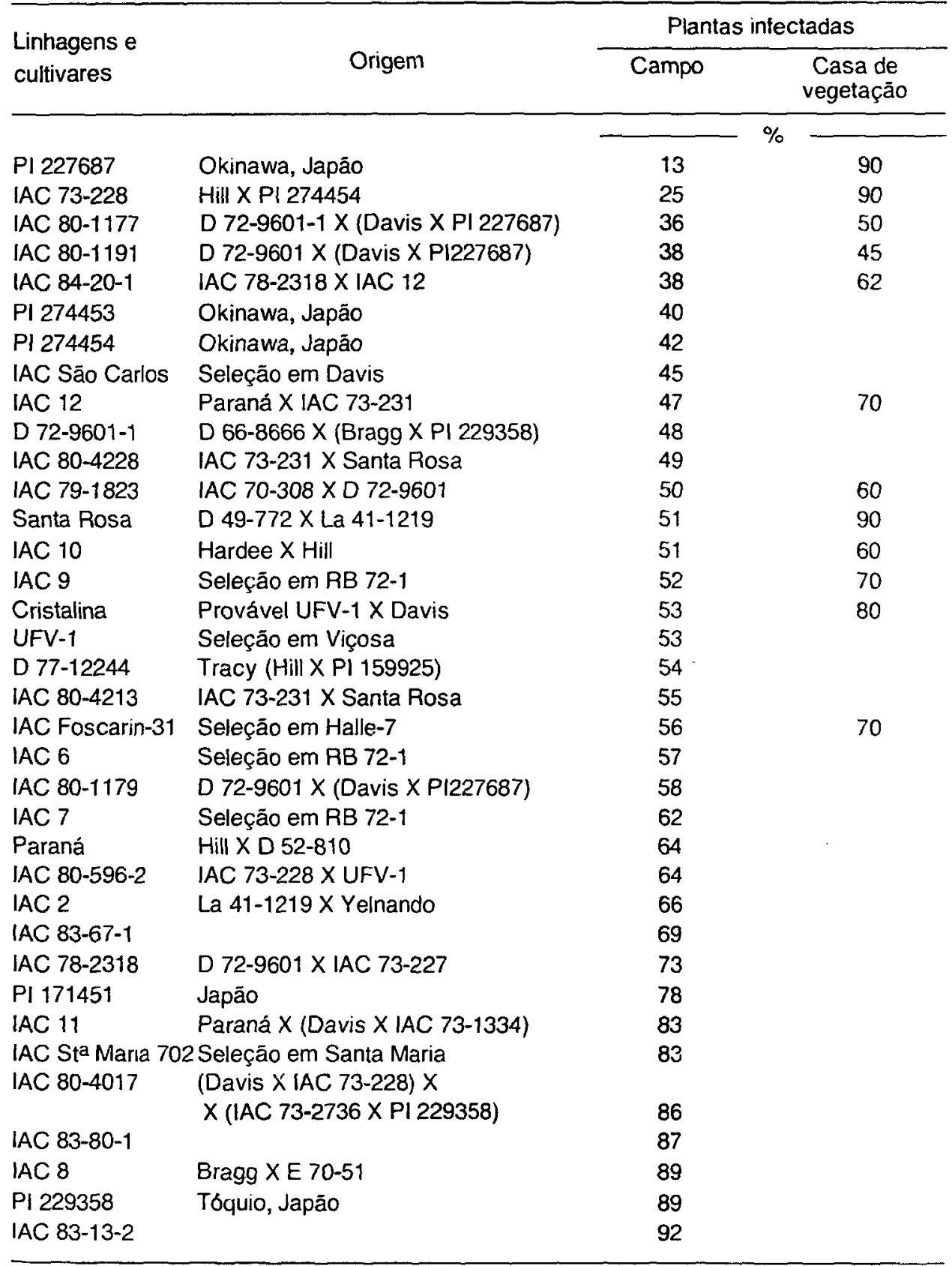


Esse material foi semeado em 27-11-1985, obedecendo a um delineamento de blocos ao acaso, com 36 tratamentos e cinco repetiçōes. Cada parcela foi formada por uma linha de $2 \mathrm{~m}$, com densidade aproximada de vinte plantas por metro linear e espaçamento de 0,6m. Não foram feitas aplicações de inseticidas nesse campo durante todo o experimento. Avaliou-se incidência da queima-do-broto, em 25-2-1986, época em que as plantas apresentavam sintomas finais da moléstia. Contou-se em cada parcela o número total e o número de plantas com sintomas do virus para obtenção do percentual de plantas infectadas.

\section{Experimento em casa de vegetação}

Nos testes de inoculação mecânıca, avaliaram-se os cinco genótipos que melhor se comportaram no experimento de campo, mais a linhagem IAC 79-1823 e os cultivares IAC 9, IAC 10, IAC 12, IAC Foscarin-31, Santa Rosa e Cristalina (Quadro 1). Esses diferentes genótipos foram semeados em vasos troncônicos de alumínio de $15 \mathrm{~cm}$ de diâmetro superior por $16 \mathrm{~cm}$ de altura; após o desbaste, permaneceram duas plantas por vaso, num total de cinco vasos para cada genótipo. As inoculações foram feitas com cinco isolados diferentes do vírus da queima-do-broto nas plantas de soja com o primeiro par de folhas primárias apenas. As preparaçōes virais foram extraidas de tolhas novas de plantas de fumo infectadas, em presença de tampão fosfato $0,02 \mathrm{M} \mathrm{pH} \mathrm{7,} \mathrm{ao} \mathrm{qual} \mathrm{se} \mathrm{adicio-}$ nou sulfito de sódio para alcançar também a concentração de $0,02 \mathrm{M}$. As inoculações foram repetidas quando as indicadoras para controle de inóculo (fumo TNN) mostraram que as preparaçōes tinham baixa concentraçāo do vírus. Os testes foram repetidos em duas ocasiōes diferentes, perfazendo um mínimo de vinte plantas avaliadas para cada genótipo.

\section{Resultados e Discussão}

No experimento de campo, os sintomas começaram a aparecer pouco antes do florescimento, quando se observou a paralisação do crescimento e posterior morte dos brotos apicais. Verificaram-se também outros sintomas da doença, como necrose das nervuras, superbrotamento e necrose do tecido da medula.

A infecção natural foi alta e generalizada, permitindo discriminar o germoplasma estudado (Quadro 1). Os acessos que apresentaram os menores índices de infecção, ou seja, igual ou inferior a $42 \%$, são portadores de resistência a uma ou mais espécies de insetos: PI 227687, introdução com resistência múltipla, conforme sumarizado por KOGAN (1989); IAC 73-228, linhagem resistente a percevejos (MIRANDA et al., 1979) e à lagarta-enroladeira, Hedylepta indicata (Fabr.) 
(LOURENÇÃO et al., 1985); IAC 80-1177 e IAC 80-1191, linhagens com bom comportamento em relação a percevejos em testes preliminares conduzidos no IAC; IAC 84-20-1, linhagem resistente a percevejos, e PI 274453 e PI 274454, introduçōes resistentes a $H$. indicata (LOURENÇÃO et al., 1985). Pl 171451 e PI 229358, também portadores de resistência múltipla a insetos (KóOGAN, 1989), situaram-se entre os acessos com maior indice de infecçāo, UFV-1, referido como material tolerante à queima-do-broto $\left({ }^{7}\right)$, exibiu $53 \%$ de plantas infectadas, comportamento esse inferior ao das linhagens mais resistentes. Entre o material comercial, somente IAC São Carios e IAC 12 apresentaram menos de 50\% de infecção.

No experimento de casa de vegetação, não se observou reação semeInante à do campo (Quadro 1). PI 227687 e IAC 73-228, que foram os mais resistentes em campo, tiveram o maior índice de plantas infectadas: $90 \%$. Essas discrepâncias entre os resultados obtidos em campo e os observados em casa de vegetação sugerem que o melhor comportamento de alguns genótipos naquele experimento não resultou da resistência da planta ao vírus. Isso, aliado ao conhecimento de que os genótipos estuciados têm resistência a insetos, indica que o tipo de resistência encontrado deve ser considerado como resistência de campo, relacionada com a interação planta-tripes vetor.

\title{
SUMMARY
}

\section{FIELD RESISTENCE TO BRAZILIAN BUD BLIGHT IN SOYBEAN GENOTYPES RESISTANT TO INSECTS}

\begin{abstract}
Brazilian bud blight, a soybean disease caused by the tobacco streak virus, is prevalent in a few areas in the States of Parana and São Paulo. Although the virus is seed-transmitted, outbreaks of the disease are related to the presence of virus in donor plants in the weed vegetation and not to seed sources. Species of Frankliniella act as vectors. Thirty six soybean genotypes, about half of them known to have varying degrees of resistance to insects, were evaluated when exposed to natural infection by bud blight in five replicated plots sown in an area where medium to severe outbreaks of the virus had occurred in previous years. Incidence, of bud blight was high in the experiment and reached $90 \%$ infection for some of the genotypes. Best genotypes for resistance to bud blight were PI 227687 (13\% infection), IAC 73-228 (25\%), IAC 80-1177 (36\%), IAC 80-1191 and IAC 84-20-1 (both 38\%), and PI 274453 (40\%). The best five most resistant genotypes mentioned above plus seven others were also screened by mechanical inoculation of greenhouse plants with five isolates of the soybean bud blight virus. The results were not parallel to those read in the field
\end{abstract}

(7) SEOIYAMA, TUNEO, 1973. Informaçāo pessoal a J.T. Yorınorı. In: A.S. Costa, Summa Phytopathologica, 3:3-30, 1977. 
exposure test. Thus, the response of PI 227687, IAC 73-228 and probably those of some of the other best genotypes are not considered the result of plant resistance to the virus, but rather as field resistance related to the interaction plant/thrips vector.

Index terms: Glycine max (L.) Merrill, resistance to insects, thrips, Frankliniella.

\section{REFERÊNCIAS BIBLIOGRÁFICAS}

COSTA, A.S. Investigações sobre moléstias da soja no Estado de São Paulo. Summa Phytopathologica, Piracicaba, 3:3-30, 1977.

\& LIMA NETO, V. da C. Transmissão do virus da necrose branca do fumo por Frankliniella sp. Revista da Sociedade Brasileira de Fitopatologia, Piracicaba, 9:36,68, 1976.

\& KIIHL, R.A.S. Transmissão do vírus da necrose branca do fumo na semente da soja. Revista da Sociedade Brasileira de Fitopatologia, Piracicaba, 4:35-36, 1971.

; MIYASAKA, S. \& PINTO, A.J. D'A. Queima dos brotos da soja, uma moléstia causada pelo vírus da necrose branca ou couve. Bragantia, Campinas, 14:VII-X, 1955. (Nota, 3)

KOGAN, M. Plant resistance in soybean insect control. In: WORLD SOYBEAN RESEARCH CONFERENCE, 4., Buenos Aires, 1989. Proceedings. p.1519-1525.

LOURENÇĀO, A.L.; ROSSETTO, C.J. \& MIRANDA, M.A.C. de. Resistência de soja a insetos. IV. Comportamento de cultivares e linhagens em relação a Hedilepta indicata (Fabr.). Bragantia, Campinas, 44(1):149-157, 1985.

MIRANDA, M.A.C. de; ROSSETTO, C.J.; ROSSETTO, D., BRAGA, N.R.; MASCARENHAS, H.A.A.; TEIXEIRA, J.P.F. \& MASSARIOL, A. Resistência de soja a Nezara viridula e Piezodorus guildini em condições de campo. Bragantia, Campinas, 38:181-188, 1979. 